\title{
Aspergillus oryzae and Beauveria bassiana as entomopathogenic fungi of Spodoptera litura Fabricius (Lepidoptera: Noctuidae) infesting corn in Lampung, Indonesia
}

\author{
Yuyun Fitriana ${ }^{1 *} \mathbb{D}$, Radix Suharjo ${ }^{1}$, I. Gede Swibawa', Bihikmi Semenguk², Lita Theresia Pasaribu², \\ Maman Hartaman ${ }^{3}$, Ruruh Anjar Rwandini ${ }^{3}$, Indriyati Indriyati ${ }^{1}$, Purnomo Purnomo ${ }^{1}$ and Solikhin Solikhin ${ }^{1}$
}

\begin{abstract}
Background: Spodoptera litura Fabricius (Lepidoptera: Noctuidae) is an important pest causing severe damage to many cultivating plants such as corn worldwide, including Indonesia. This study was performed to obtain and identify entomopathogenic fungi (EPF) of $S$. litura collected from corn fields in 4 corn producing regions of Lampung, Indonesia, as well as to investigate the damage caused by this pest on corn in Lampung Province.

Results: Three corn fields in each region were selected for collecting soil samples. Soil samples were collected from 5 corn plant rhizospheres, at each field in six months of survey. Ten larvae of Tenebrio molitor Linnaeus (Coleoptera: Tenebrionidae) were laid on each soil sample as a bait, covered with a filter paper and incubated at room temperature. The emerging fungi from T. molitor cadaver were transferred onto Potato Dextrose Agar (PDA) medium and incubated for 7 days at room temperature. Pathogenicity test was determined against 3 rd instar of $S$. litura larvae. Identification was performed based on the sequence of Internal Transcribed Spacer (ITS) Region. Observations on the corn damage caused by $\mathrm{S}$. litura were conducted at all corn producing areas in Lampung. Twelve fungal isolates were obtained causing $0-75 \%$ of mortality of $S$. litura. Four fungal isolates (NKPT, SKHJ, SDHJ and RAHJ), which caused mortality more than 20\%, were further identified. One isolate (NKPT) was confirmed as Beauveria bassiana and the other 3 isolates (SKHJ, SDHJ and RAHJ) were Aspergillus oryzae. S. litura generally caused slight damages to the corn which was found in every observation year performed during 2010-2019. Medium plant damage was observed in 2010-2012 and 2018-2019, severe damage was found in 2011 and crop failure was recorded in 2018.
\end{abstract}

Conclusions: Aspergillus oryzae and B. bassiana were the EPF recorded infecting S. litura in corn in Lampung Province. This was the first report on the isolates of A. oryzae as EPF of $S$. litura in Indonesia. Slight damages with S. litura were always recorded in every observation year but not for those of medium and severe damages and crop failure.

Keywords: Corn, Spodoptera litura, Entomopathogenic fungi, Tenebrio molitor, ITS region, Pathogenicity

*Correspondence: yuyun.fitriana@fp.unila.ac.id

${ }^{1}$ Department of Plant Protection, Faculty of Agriculture, University

of Lampung, Jl. Soemantri Brojonegoro No. 1, Bandar Lampung, Indonesia Full list of author information is available at the end of the article

\section{Background}

The tobacco caterpillar, Spodoptera litura Fabricius (Lepidoptera: Noctuidae) is one of the economic pest causing serious damages in a large number of cultivating plants worldwide (Bragard et al. 2019) as well as in Indonesia (Ngatimin and Nasruddin 2019), covering 40 plant families (Bragard et al. 2019). It has been reported that $S$. 
litura has a high migratory ability and is widely distributed in both tropical and temperate regions. A report in the Philippines confirmed that S. litura caused moderate to severe damages to corn (Gerpacio et al. 2004). The damage caused by this pest on corn in Lampung Province has not been fully revealed.

Recently, the use of insecticides for controlling S. litura has continuously increased, making it possible to become resistant. It has been reported that $S$. litura is now being resistant to several groups of insecticides resulting in more difficulties for controlling it. The increase in public awareness on the negative impacts on the use of pesticide, especially on human health and environment has led to finding and developing alternative control strategies eco-friendly. One of which is using entomopathogenic fungi (EPF). Application of EPF has no harmful residues and improves the balance of the bionetwork within the ecosystem. Once the EPF has spread in host populations, it provides lifetimes of pest control (Scheepmaker and Butt 2010).

Exploration to obtain biological control agents, including EPF is the first step in the implementation of the biological control techniques. The EPF can be obtained from the infected insects, soils or plants' rhizosphere (Singh et al. 2016). Tesfaye and Seyoum (2010) reported that temperature conditions were one of the factors that influenced pathogenicity of the isolate of EPF. Since the temperature condition varies among regions, indigenus EPF can be one of the alternatives to provide better results since they are more adapted to the local environment (Sayed et al. 2019).

This study was performed to obtain and identify EPF of S. Litura, collected from corn field in 4 corn producing areas in Lampung Province, as well as the potential of EPF against the pest on corn fields in the Province.

\section{Methods \\ Sampling}

Soil samples were collected from corn rhizosphere in 4 regions (districts), namely Bandar Lampung, Pesawaran, Lampung Selatan and Lampung Timur. Three corn fields with a minimum area of $50 \mathrm{~m}^{2}$ were selected in each region. One corn field was selected in each sub-district. Soil samples were collected from 5 corn plant rhizospheres at $10-15 \mathrm{~cm}$ of depth, which were diagonally and randomly chosen. As much as $500 \mathrm{~g}$ of soil were taken from each plant's rhizosphere and composited. Totally, $1000 \mathrm{~g}$ of the composite soil sample from each field was collected and brought to the laboratory.

\section{Isolation of Entomopathogenic fungi}

Isolation of the potential EPF was performed in the Laboratory of Agricultural Biotechnology, Faculty of
Agriculture, University of Lampung, Indonesia, using baiting method (Tarasco et al. 2020). The soil samples were sieved by a 600 mesh strainer and moved into plastic trays $(35 \times 28 \times 7 \mathrm{~cm})$. Ten larvae of Tenebrio molitor Linnaeus (Coleoptera: Tenebrionidae) were placed on the soil and covered with filter paper. The trays were then incubated in a dark condition at room temperature. Observation was performed for 14 days on the fungus, which emerged on the body surface of $T$. molitor. The infected T. molitor larvae were sterilized by dipping in $1 \%$ sodium hypochlorite $(\mathrm{NaOCl})$ for $30 \mathrm{~s}$. The emerging fungus was taken and cultivated on Potato Dextrose Agar (PDA) medium (Himedia, India) and incubated for 7 days at room temperature.

\section{Pathogenicity test of the obtained entomopathogenic fungi}

The 3rd instar larvae of S. litura were used for pathogenicity tests. Ten larvae were placed into sterile plastic petri dish (9 $\mathrm{cm}$ of diameter) containing 7 days old fungi, which were obtained from $T$. molitor. The larvae of $S$. litura were rolled over to make sure that the body surface of the larvae was completely covered by the mycelium or conidia of the fungi. The larvae were then transferred into plastic jars (14 cm of diameter) containing fresh leaves of Ricinus communis Linnaeus (Malpighiales: Euphorbiaceae) as food. For the control, the healthy Spodoptera larvae were directly placed into a plastic jar. Observation was performed for 14 days on the deaths of S. litura. Percentage of mortality (PM) was calculated using formula $[(\mathrm{a} / \mathrm{b}) \times 100 \%] ; \mathrm{a}=$ number of the death of S. litura; $\mathrm{b}=$ Total of $S$. litura observed.

\section{Identification of the entomopathogenic fungi}

Identification, conducted to the fungi causing death of Spodoptera larvae, was performed based on the sequence analysis of the Internal Transcribed Spacer (ITS) region.

\section{DNA extraction}

DNA extraction was conducted based on the method performed by Swibawa et al. (2020). The conidia of 7 days old of Aspergillus and 21 days old of Beauveria (those were cultured on PDA in sterile plastic petri dish with $9 \mathrm{~cm}$ in diameter) were harvested by added with $10 \mathrm{ml}$ of sterile distillate water and carefully grabbed using drigalski. The suspension was then transferred into a $30 \mathrm{ml}$ of centrifuge tube and centrifuged at 14,000 rpm for $10 \mathrm{~min}$, using CF15RXII (Hitachi, Japan). After centrifugation, $1 \mathrm{~mL}$ of $70 \%$ cold ethanol was directly added into the tube and centrifuged at $14,000 \mathrm{rpm}$ for $10 \mathrm{~min}$. The supernatant was then removed and $1 \mathrm{~mL}$ of extraction buffer (0.5 mL Tris $\mathrm{HCl}, 1 \mathrm{~mL}$ SDS $1 \%+2.8 \mathrm{~mL} \mathrm{NaCl}, 0.2 \mathrm{~mL}$ 
Mercaptoethanol, $2 \mathrm{~mL}$ EDTA, $3.5 \mathrm{~mL}$ sterile water) was added to the tube and suspended. The pellet suspension was shifted into a mortar and incubated at $40{ }^{\circ} \mathrm{C}$ for $24 \mathrm{~h}$. After incubation, the frizzed suspension was pounded until completely crushed. In total, $500 \mu \mathrm{L}$ of pellet suspension was transferred into a $1.5-\mathrm{mL}$ tube. As much as $400 \mu \mathrm{L}$ of $2 \%$ cetyl trimethylammonium bromide (CTAB) was added, gently homogenized and incubated at $65{ }^{\circ} \mathrm{C}$ for $1 \mathrm{~h}$, using a water bath (Brookfield TC $550 \mathrm{MX}-230$, USA). After incubation, $500 \mu \mathrm{L}$ of Phenol Chloroform Isoamyl Alcohol (PCI) solution (25: 24: 1) was added, hardly homogenized, and centrifuged at 14,000 rpm for $10 \mathrm{~min}$. In total, $600 \mu \mathrm{L}$ supernatant was conveyed into a new $1.5-\mathrm{mL}$ tube. As much as $600 \mu \mathrm{L}$ of Chloroform Isoamyl Alcohol (CI) solution (24:1) was added, homogenized, and centrifuged at $14,000 \mathrm{rpm}$ for $10 \mathrm{~min}$. Totally, $400 \mu \mathrm{L}$ of the supernatant was relocated into a new $1.5-\mathrm{mL}$ tube. As much as $400 \mu \mathrm{L}$ cold isopropanol was added into the tube, gently homogenized by hand, and incubated at $-40{ }^{\circ} \mathrm{C}$ for $20 \mathrm{~min}$. After incubation, the tube was centrifuged at $14,000 \mathrm{rpm}$ for $15 \mathrm{~min}$. The supernatant was discharged, and $500 \mu \mathrm{L}$ of cool $70 \%$ ethanol was added and centrifuged at $14,000 \mathrm{rpm}$ for $5 \mathrm{~min}$. The supernatant was discharged, and the pellet obtained was air-dried at room temperature for $24 \mathrm{~h}$. After air-dried, $50 \mu \mathrm{L}$ $1 \times$ Tris-HCL EDTA (TE) pH 8.0 (1st Base Malaysia) was added. All centrifugation processes after incubation at $-40{ }^{\circ} \mathrm{C}$ were performed using a centrifuge Microspin12 (Biosan, Latvia).

\section{PCR amplification}

Amplification was conducted with Sensoquest Thermal Cycler Machine (Germany). PCR amplification was performed on Internal Transcribed Spacer (ITS) region, using primer ITS1 (5'TCC GTA GGT GAA CCT TGC GG 3') and ITS4 (5'TCC TCC GCT TAT TGA TAT GC 3') (White et al. 1990). PCR was performed in total volume $25 \mu \mathrm{L}$ consist of $12.5 \mu \mathrm{L}$ Master Mix (Red Mix) (bioline), $1 \mu \mathrm{L}$ of $10 \mu \mathrm{M}$ of primer ITS 1 and ITS $4,1 \mu \mathrm{L}$ DNA template $(\sim 1 \mu \mathrm{g} / \mu \mathrm{L})$ and $9.5 \mu \mathrm{L}$ sterile distilled water. DNA amplification covering one cycle of the initiation at $95{ }^{\circ} \mathrm{C}$ for $5 \mathrm{~min}, 30$ cycles of denaturation at $95^{\circ} \mathrm{C}$ for $1 \mathrm{~min}$, annealing at $46-52^{\circ} \mathrm{C}$ for $1 \mathrm{~min}$, primer extension at $72{ }^{\circ} \mathrm{C}$ for $1 \mathrm{~min}$, and one cycle of elongation at $72{ }^{\circ} \mathrm{C}$ for $5 \mathrm{~min}$. The PCR results were electrophoresed by $0.5 \%$ agarose gel suspended in $20 \mathrm{~mL} 1 \times$ buffer Tris-Boric Acid-EDTA (TBE) (1st Base Malaysia) containing $1 \mu \mathrm{L}$ Ethidium Bromide (EtBr $10 \mathrm{mg} / \mathrm{mL}$ ). The electrophoresis was conducted using a $1 \times$ TBE buffer at $50 \mathrm{~V}$ for $70 \mathrm{~min}$. The results were visualized using DigiDoc UV transilluminator (UVP, USA).

\section{Sequencing and analysis of the result}

The PCR product was sent to 1st Base Malaysia for sequencing. The sequencing results were analyzed using Bio Edit program ver. 7.2.6 for windows and submitted to Basic Local Alignment Search Tool (BLAST) (https:// blast.ncbi.nlm.nih.gov/Blast.cgi) to obtain the possible identity. The dendrogram was constructed using Mega 7 program for Windows (Kumar et al. 2016) by neighbor joining method (jukes and cantor model). Reference strains used in this study were downloaded from NCBI (https://www.ncbi.nlm.nih.gov/). Detailed information of the reference strains is shown in Additional file 1: Table S1.

\section{Aflatoxin production test}

Assessment was performed on the Aspergillus spp. showed capability to cause death of S. litura based on method described by Fente et al. (2001). The 7 days old isolates of Aspergillus spp. were cultivated on yeast extract with supplements (YES) medium (Himedia, India) added to $2 \%$ of methyl- $\beta$-cyclodextrin (Sigma Aldrich, USA) and incubated at room temperature. An isolate of A. flavus BIO 3338, an aflatoxigenic fungi collection of Indonesian Culture Collection (InaCC), which was isolated from diseased peanuts, was used as positive control. Observation was performed 5 days after incubation under UV light $(356 \mathrm{~nm})$. Aflatoxigenic isolates showed fluorescence but not for non-aflatoxigenic isolates (Fente et al. 2001).

\section{Corn damage caused by Spodoptera litura in Lampung Province}

The damage of corn data was obtained from the survey conducted by the Crop and Horticultural Plant Protection Agency of Lampung Province from 2010 to 2019. Survey performed in all corn producing area in Lampung (Bandar lampung, Lampung Selatan, Lampung Tengah, Lampung Timur, Lampung Utara, Lampung Barat, Metro, Pesawaran, Tulang Bawang, Tulang Bawang Barat, Pesisir Barat and Way Kanan, Pringsewu), using method described by Direktorat Perlindungan Tanaman Pangan (2018). The data collected in this study was the damaged area caused by $S$. litura which were divided into 4 levels namely slight ( 1 to $\leq 25 \%$ of plant damage), medium $(>25$ to $\leq 50 \%$ of plant damage), severe ( $>50$ to $\leq 85 \%$ of plant damage), and crop failure ( $>85 \%$ of plant damage).

\section{Weather data in Lampung Province}

Rainfall and rainy days were collected from ombrometer collected from 15 sub-districts in Lampung Province, during the years of 2013-2019. Minimum and maximum temperature data were obtained from Statistics of Lampung Province during the year of 2010-2017, which can 
be freely downloaded from https://lampung.bps.go.id/ subject/151/iklim.html\#subjekViewTab3.

\section{Statistical analyses}

Pathogenicity test was arranged using Completely Randomized Design (CRD) with 3 replicates. The data was analyzed by one-way analysis of variance (ANOVA). If there is a significant difference between the means of two or more isolates, further analysis was carried out using Least Significant Difference (LSD) test. Statistical analysis was performed with R Statistical Software (version 4.1.1; R Foundation for Statistical Computing, Vienna, Austria).

\section{Results}

Fungal isolates obtained from infected Tenebrio molitor

Totally, 12 fungal isolates were recovered from the infected T. molitor larvae (Additional file 2: Fig. S1) which were previously laid on the 8 soil samples as lure of EPF, i.e., Kemiling Permai (1 isolate), Rajabasa Raya (1 isolate), Sukaraja (2 isolates), Natar (2 isolates), Sidosari (2 isolates), Rejoagung (1 isolate), Negeri Katon (2 isolates) and Balerejo (1 isolate). The samples were collected from the corn rhizosphere of different varieties, namely sweet corn, NK 22, P27 and an unknown variety representing local varieties planted by the farmers. Eight of the fungal isolates showed white colony color, 3 isolates had green colony color and the other 1 isolate showed black colony color (Table 1).

\section{Pathogenicity of the obtained entomopathogenic fungi to Spodoptera litura}

Nine out of 12 fungal isolates showed capability to cause mortality of $S$. litura, i.e., NKPT, SKHJ, SDHJ, RAHJ, SDPK and RRPK. Six of the isolates produced mortality less than 50\%, namely NTHT (3.33\%), BRPT (3.33\%), NKPT (3.70\%), SDPK (6.67\%), RRPK (7.41\%) and RAHJ (24.44\%) and the other 3 isolates produced more than $50 \%$ of mortality, i.e., NKPT (74.07\%), SKHJ (60.37\%) and SDHJ (50.74\%) (Fig. 1). Further identification was conducted on the 4 EPF causing mortality of $S$. litura more than $20 \%$, namely NKPT (74.07\%), SKHJ (60.37\%), SDHJ (50.74\%) and RAHJ (25\%) (Fig. 2).

\section{Identity of the entomopathogenic fungi}

The result of BLAST searches revealed that NKPT shared 99.62\% similarity to B. bassiana (Bals.) Vuill. (Hypocreales: Cordycipitaceae) isolate ERL923 (Acc. No. MN122413); meanwhile SKHJ, SDHJ and RAHJ were shared $100 \%$ similarity with Aspergillus aflatoxiformans Frisvad, Ezekiel, Samson \& Houbraken (Eurotiales: Trichocomaceae) and Aspergillus flavus Link (Eurotiales: Trichocomaceae) and Aspergillus oryzae (Ahlb.) Cohn. (Eurotiales: Trichocomaceae). The result of BLAST was confirmed by the phylogenetic tree. The NKPT isolate was placed within a group of B. bassiana ARSEF 7518 (ACC. No. HQ880762), ARSEF 296 (Acc. No. AY532013) and ARSEF 937 (Acc. No. AY532056) (Fig. 3); meanwhile SKHJ, SDHJ and RAHJ were placed in the group of $A$. aflatoxiformans, A. flavus and A. oryzae (Fig. 4).

Further investigation to verify the identity of SKHJ, $\mathrm{SDHJ}$ and RAHJ isolates was conducted on their capability to produce aflatoxin using YES medium supplemented with $2 \%$ of methyl- $\beta$-cyclodextrin described by Fente et al. (2001). The group of A. flavus and A. aflatoxiformans were reported as producing toxin Aspergillus but not for $A$. oryzae. One isolate of producing toxin A. flavus BIO 3338 was also included. The result showed that the A. flavus BIO 3338 showed green

Table 1 Fungal isolates obtained from infected Tenebrio molitor

\begin{tabular}{|c|c|c|c|c|c|c|}
\hline \multicolumn{2}{|l|}{ Regions } & \multirow[t]{2}{*}{ Ordinate } & \multirow[t]{2}{*}{ Corn varieties } & \multirow{2}{*}{$\begin{array}{l}\text { Plant age (days } \\
\text { after planting) }\end{array}$} & \multirow{2}{*}{$\begin{array}{l}\text { Name of } \\
\text { the isolate }\end{array}$} & \multirow{2}{*}{$\begin{array}{l}\text { Colony color } \\
\text { on PDA } \\
\text { medium }\end{array}$} \\
\hline Districts & Sub-districts & & & & & \\
\hline \multirow[t]{2}{*}{ Bandar Lampung } & Kemiling Permai & $-5.3822191,105.2201871$ & Sweet corn & 10 & KPPK & White \\
\hline & Rajabasa Raya & $-5.348984,105.244406$ & & 50 & RRPK & \\
\hline \multirow[t]{6}{*}{ Lampung Selatan } & Sukaraja & $-5.685002,105.673718$ & Sweet corn & 42 & SKPK & \\
\hline & & & & & SKHJ & Green \\
\hline & Natar & $-5.343718,105.230879$ & NK22 & 60 & NTPK & White \\
\hline & & & & & NTHT & Black \\
\hline & Sidosari & $-5.322588,105.250467$ & Sweet corn & 60 & SDPK & White \\
\hline & & & & & $\mathrm{SDHJ}$ & Green \\
\hline \multirow[t]{3}{*}{ Pesawaran } & Rejoagung & $-5.183594,105.200795$ & P27 & 15 & $\mathrm{RAHJ}$ & \\
\hline & Negeri Katon & $-5.311441,105.1041564$ & & 30 & NKPT & White \\
\hline & & & & & NKPK & \\
\hline Lampung Timur & Balerejo & $-5.1094025,105.3831026$ & Unknown (local variety) & 60 & BRPT & \\
\hline
\end{tabular}




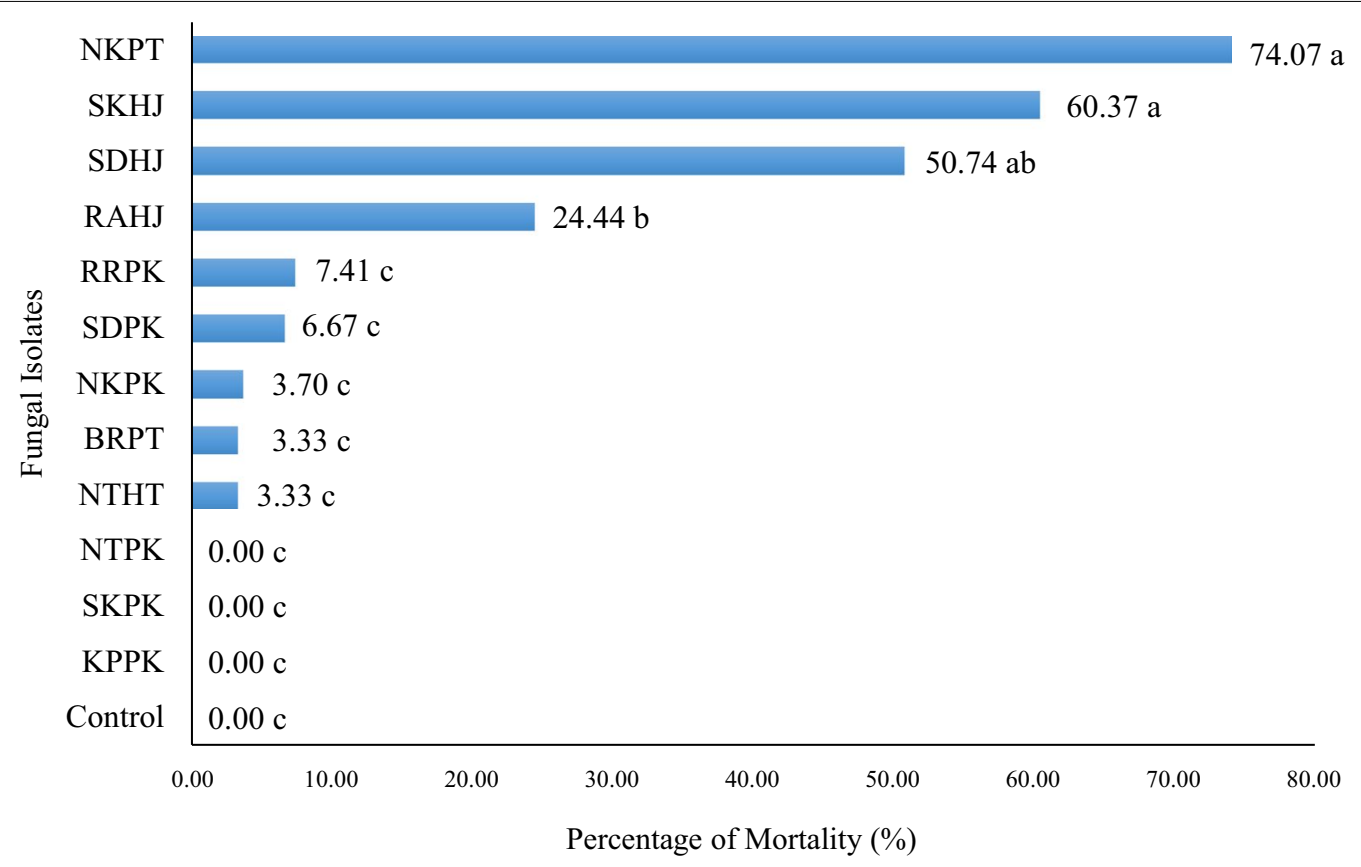

Fig. 1 Percentage of mortality of Spodoptera litura caused by fungal application. The numbers followed by the same letter are not significantly different based on least significant difference test (LSD) analysis at the $5 \%$ of significance level. Statistical analysis was performed on the data which were transformed using $\sqrt{ } x+0.5$. Treatments were arranged using a completely randomized design (CRD). The data are means collected from observation of the mortality of 10 individuals of $S$. litura applied with entomopathogenic fungi. Assessment was conducted in 3 replicates

fluorescence but not for SKHJ, SDHJ and RAHJ (Fig. 5). Inability SKHJ, SDHJ and RAHJ produced green fluorescence indicated that the three isolates were not able to produce aflatoxin, confirming that SKHJ, SDHJ and RAHJ were A. oryzae.

\section{Corn damage caused by S. litura in Lampung Province}

The invasion of $S$. litura mostly caused slight damage on corn ( 1 to $\leq 25 \%$ of plant damage). The damaged area generally decreased, from 717 ha in 2010 to 169 ha in 2019. The lowest damaged area was found in 2015, which affected 10 ha with slight plant damage with no record of medium damage, severe damage and crop failure. Medium plant damage occurred in 2011, 2012, 2018 and 2019 affected 29, 2, 3 and 1 ha of corn fields, respectively. Severe plant damage was observed in 2011, affected 25 ha of corn fields. Crop failure conditions were faced in the year 2018 affected 39 ha of corn fields (Fig. 6). The damage caused by S. litura was initially observed in January and continued rising until July. The damage decreased in August and September and again raised in October to December, with the most damage observed in November. During a year observation, the lowest damage was found in August and September (Fig. 7).

\section{Weather conditions in Lampung Province}

In January, heavy rainfall occurred $(274.70 \mathrm{~mm})$ and then decreased in the next months. During July to September, rainfall was lower than $100 \mathrm{~mm}$, with the lowest rainfall observed in August $(54.88 \mathrm{~mm})$. The rainfall increased above $100 \mathrm{~mm}$ in October $(103.64 \mathrm{~mm})$ and increased until December $(256.14 \mathrm{~mm})$. The highest rainy days were observed in January (19.39 days) and continue to decrease in the months after. The smallest rainy days occurred in August (2.52 days) and September (2.83 days). The amount of rain increased in October (4.05 days) and continued until December (13.89 days). The minimum temperatures were $22.15-$ $23.66{ }^{\circ} \mathrm{C}$; meanwhile the maximum temperature was in the range of $31.30-37.54{ }^{\circ} \mathrm{C}$. The highest temperature occurred in September $\left(37.54{ }^{\circ} \mathrm{C}\right)$.

\section{Discussion}

Twelve isolates of EPF were recovered from 8 soil samples collected from the districts of Bandar Lampung, Lampung Selatan, Pesawaran and Lampung Timur. The fungi were obtained by a baiting method employing $T$. molitor. Baiting method using T. molitor (Sharma et al. 2018) has been reported as one of methods used to 




Fig. 2 Prospective fungal isolates causing death of Spodoptera litura more than 20\%. a NKPT, b SKHJ, c SDHJ, d RAHJ

obtain EPF from soil such as B. bassiana (Sharma et al. 2018).

Six out of 12 fungal isolates obtained in this study were confirmed causing mortality to S. litura (3.57-75\%). The highest mortality rate was produced by NKPT (75\%), followed by SKHJ (60.71\%), SDHJ (50\%), RAHJ (25\%), SDPK (3.57\%) and RRPK (3.57\%). Some natures of EPF influenced their capability to cause death of herbivorous insects, i.e., spore production and viability (Rosmiati et al. 2018), penetration (Mora et al. 2017), infection (Santos et al. 2018) and enzymes produced by each EPF (Dhawan and Joshi 2017). Different EPF produce several enzymes and toxins. Chitinase was produced by Aspergillus spp., which can degrade chitin of fungal pathogens and pest insects (Purkan and Sayyidah 2016).

Further identification was performed on the 4 isolates which produced mortality more than 20\%, i.e., NKPT, SKHJ, SDHJ and RAHJ. Based on the BLAST search result, the NKPT was closely related with the group of
B. bassiana; meanwhile SJHJ, SDHJ and RAHJ shared $100 \%$ similarity with $A$. aflatoxiformans, A. flavus and $A$. oryzae. Based on the phylogenetic tree analysis revealed that NKPT was placed within the group of $B$. bassiana (Fig. 3); meanwhile, SJHJ, SDHJ and RAHJ were placed within a group of $A$. aflatoxiformans and A. flavus and $A$. oryzae (Fig. 4). In the case of NKPT, the isolate was $B$. bassiana; meanwhile the other 3 isolates should be carefully analyzed on their characters to define their species identity.

The genus of Aspergillus was divided into 4 subgenera (Aspergillus, Circumdati, Fumigati and Nidulantes) and 20 sections. A. oryzae is a representing domesticated group of $A$. flavus. This species can be differentiated from the other members of $A$. flavus-clade on their inability to produce aflatoxin (Frisvad et al. 2019).

The three isolates of Aspergillus found in this study (SKHJ, SDHJ and RAHJ) were confirmed on their inability to produce aflatoxin. They did not produce 


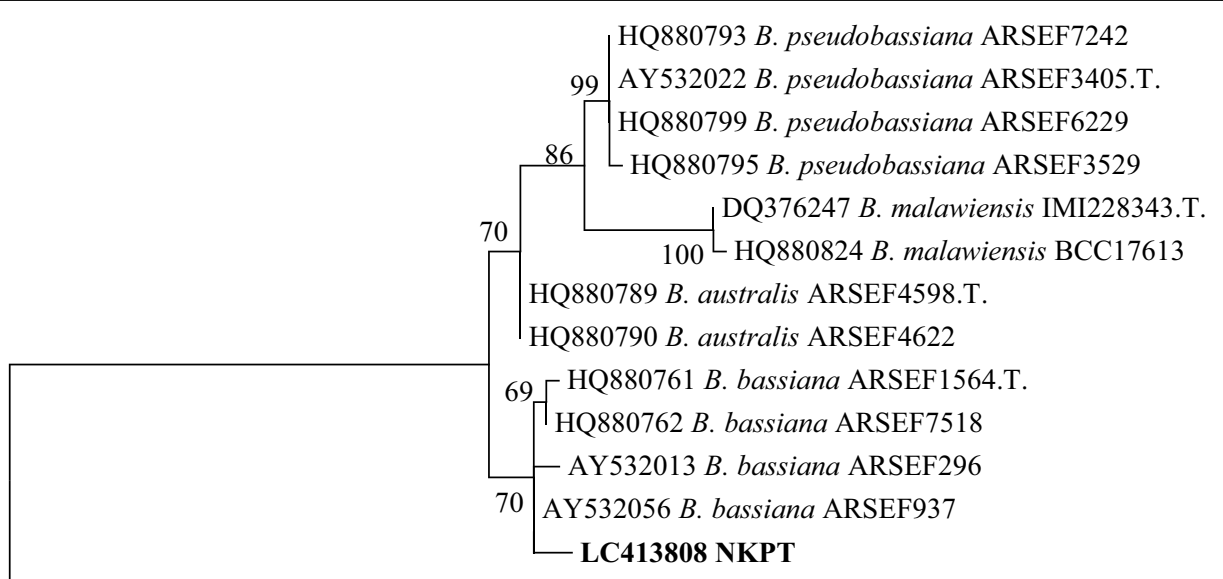

HQ331446 Metarhizium anisopliae ARSEF7487.T.

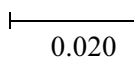

Fig. 3 Phylogenetic tree developed based on sequence analysis of ITS region by primer ITS1 and ITS4 with Maximum Likelihood method (TamuraNei model) created using MEGA7 for windows (Kumar et al. 2016). NKPT isolate placed within group of ex type and reference strains of Beauveria bassiana, i.e., ARSEF3405.T. (Acc. No. AY532022), ARSEF937 (Acc. No. AY532056), isolate ARSEF296 (Acc. no. AY532013) and ARSEF7518 (Acc. No. HQ880762). NKPT has other designations as B1_UNILA. Metarhizium anisopliae ARSEF7487.T. (Acc No. HQ331446) was used as out group. Reference strains included in this study were assembled from the study of Rehner and Buckely (2005), Rehner et al. (2006) and Rehner et al. (2011). T=ex type isolate

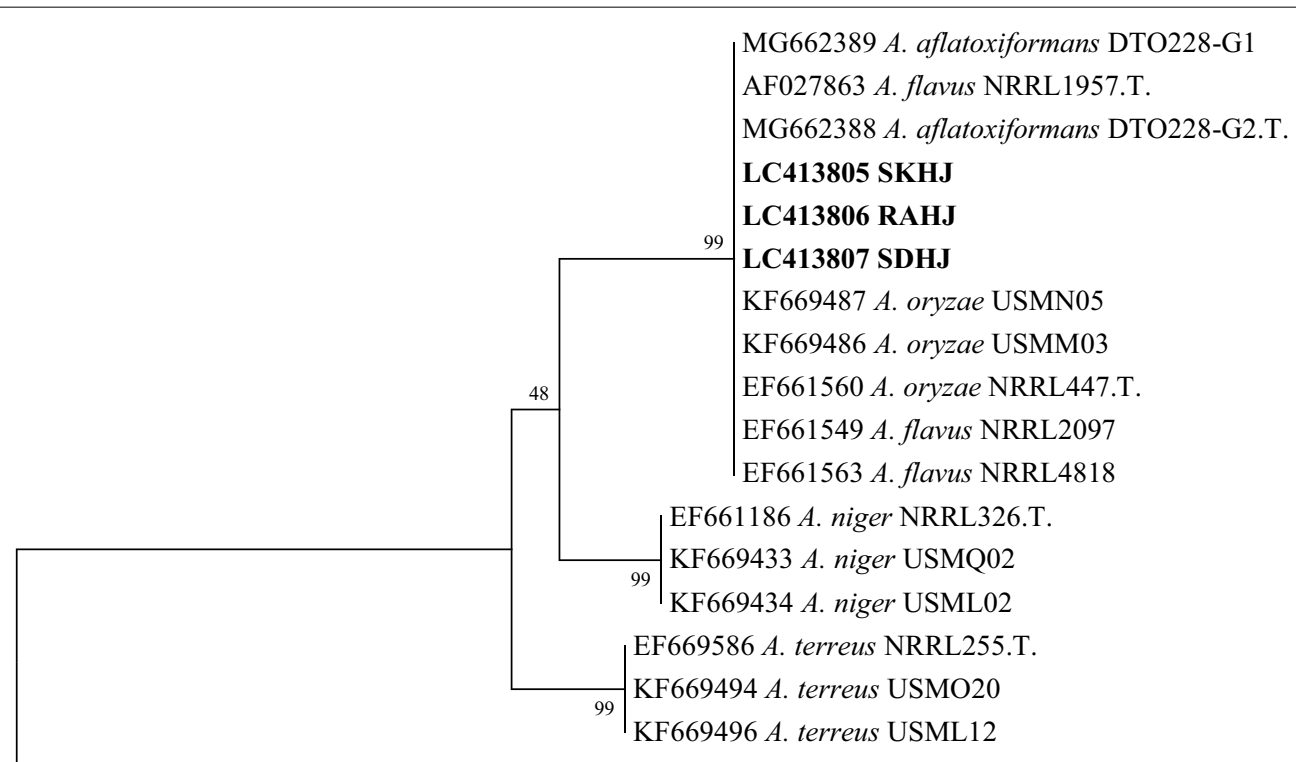

HQ331446 Metarhizium anisopliae ARSEF7487.T.

0.050

Fig. 4 Phylogenetic tree developed based on sequence analysis of ITS region by primer ITS1 and ITS4 with Maximum Likelihood method (Tamura-Nei model) created using MEGA7 for windows (Kumar et al. 2016). Isolate of SKHJ, SDHJ and RAHJ placed within group of ex type isolate and reference strains of Aspergillus oryzae (NRRL447.T., Acc. EF661560; USMN03, Acc. No. KF669486; USMN05, Acc. No. KF669487), A. flavus (NRRL1957.T., Acc. No. AF027863; NRRL2097, Acc. No. EF661549; NRRL4818, Acc. No. EF661563) and A. aflatoxiformans (DTO228-G2.T., Acc. No. MG662388; DTO228-G1, Acc. No. MG662389). SKHJ has other designations as AP6_UNILA, SDHJ has other designations as AP9_UNILA, RAHJ has other designations as AP7_UNILA. Metarhizium anisopliae ARSEF7487.T. (Acc No. HQ331446) was used as out group. Reference strains included in this study were assembled from the study of Peterson (2008), Schneider et al. (2011), Zulkifli and Zakaria (2017) and Frisvad et al. (2019). T= ex type isolate 


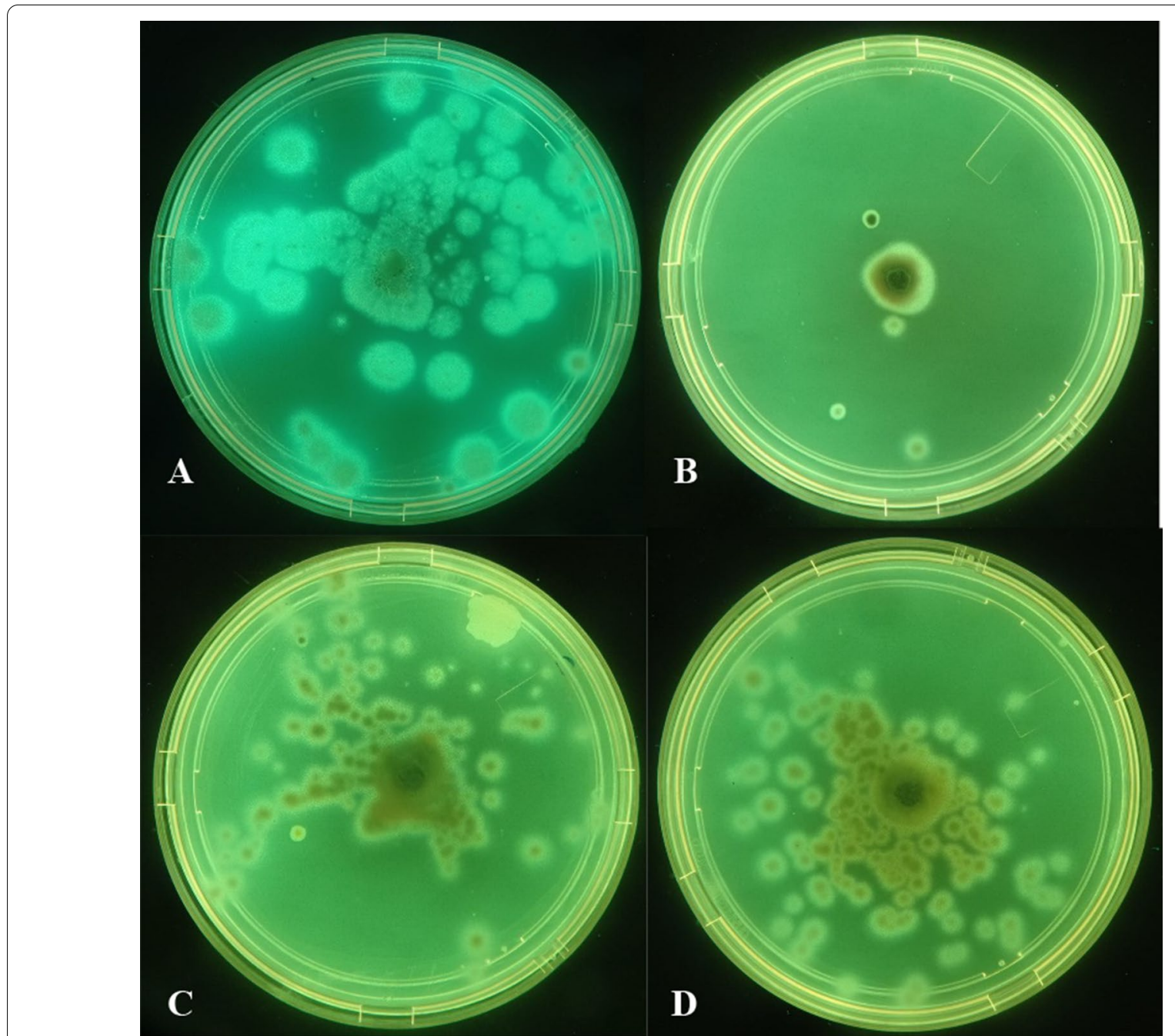

Fig. 5 Fluorescence of 5 days old Aspergillus isolate grown on YES medium supplemented with 2\% of methylated ß-cyd observed under UV light (365 nm). a A. flavus BIO 3338, b SKHJ, c RAHJ, d SDHJ

any fluorescence when they were cultured on the YES medium supplemented with $2 \%$ of methyl- $\beta$-cyclodextrin. The fluorescence was observed on A. flavus BIO 3338 , an aflatoxin producing-isolate, which was used as a positive control. YES medium, which was added by $2 \%$ of methyl- $\beta$-cyclodextrin, was reported to be used to differentiate Aspergillus aflatoxin producing-isolate from nonaflatoxin producing-isolate by its capability to produce fluorescence when it was observed under UV light (Fente et al. 2001). Here, it was concluded that SKHJ, SDHJ and RAHJ isolates were $A$. oryzae. To our knowledge, this is the first report of $A$. oryzae isolates as an EPF of S. litura in Indonesia.

Aspergillus oryzae was established and initially used for food production about 2000 years ago in China (Baker and Bennett 2008). As well as in China, this fungus is also extensively employed for food production in Japan, Korea, Thailand and Indonesia (Baker and Bennett 2008). The beneficial aspect of $A$. oryzae other than its use in food production, especially as a biological control agent, has not been widely reported. The role of $A$. oryzae as EPF was firstly reported in 2015 (Zhang et al. 2015). They described an isolate of $A$. oryzae, namely XJ-1, showed capability as EPF on locusts. In this study, the 3 isolates of $A$. oryzae (SKHJ, SDHJ and RAHJ) were found pathogenic to $S$. litura. Since A. oryzae is not pathogenic to humans, animals or plants (Chuang et al. 2019), it has Generally Regarded as Safe (GRAS) status from Food and Drug Administration (FDA) United States of America (Sewalt et al. 2016). This A. oryzae has a great potential to be developed for biological control agent of herbivorous insects. 


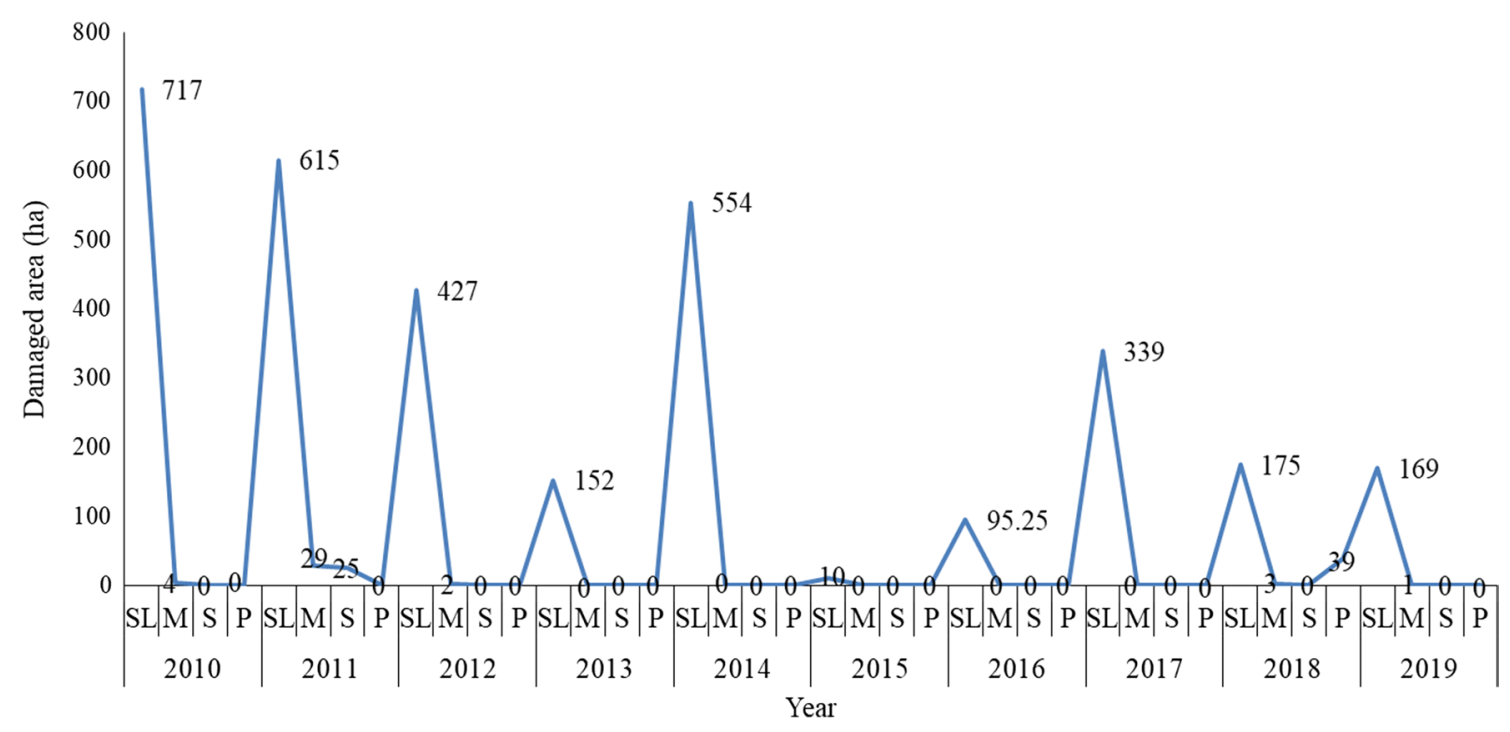

Fig. 6 Damaged area of corn field caused by Spodoptera litura in Lampung during 2010-2019. SL: slightly damage (1 to $\leq 25 \%$ of plant damage), M: medium damage ( $>25$ to $\leq 50 \%$ of plant damage), S: severe damage ( $>50$ to $\leq 85 \%$ of plant damage), P: crop failure ( $>85 \%$ of plant damage)

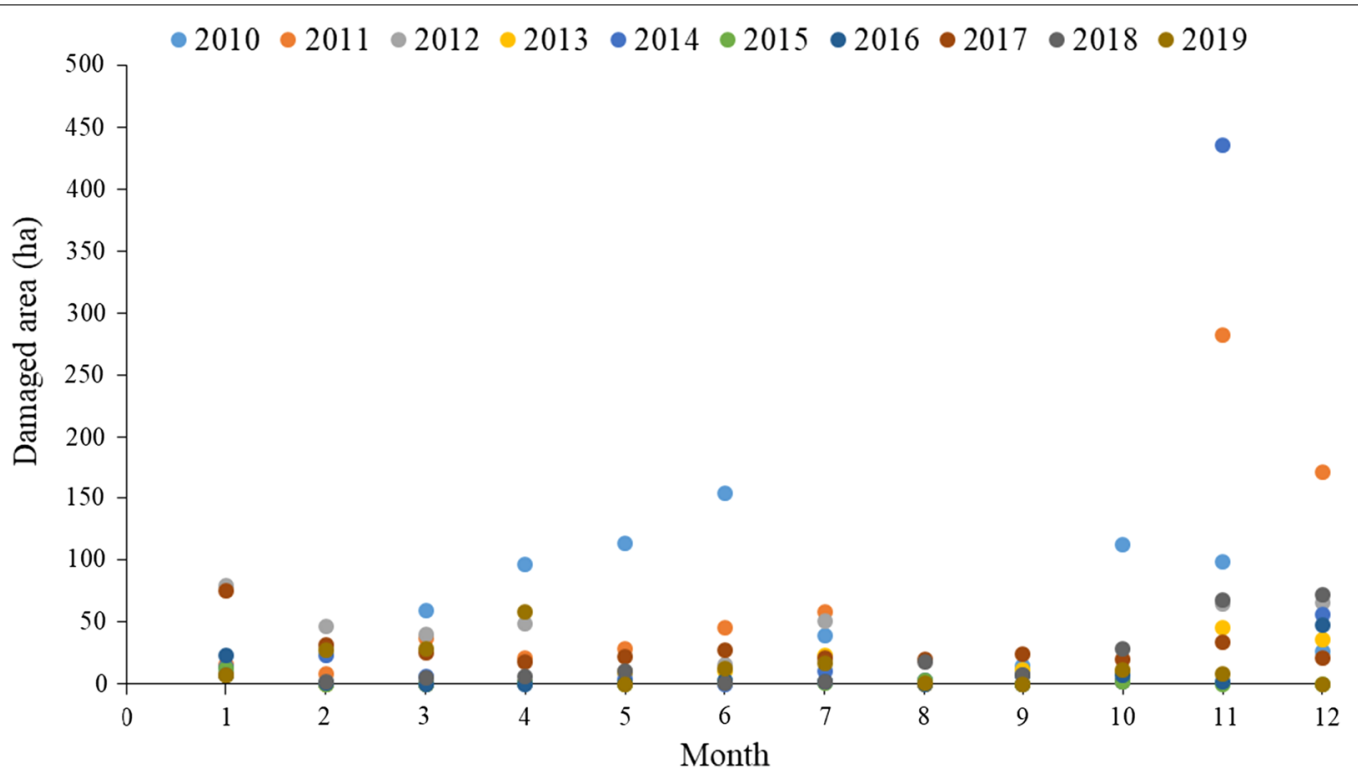

Fig. 7 Damaged area of corn field caused by Spodoptera litura in Lampung each month during 2010-2019

In this study, native corn isolates of EPF belong to $B$. bassiana (NKPT) and $A$. oryzae (SKHJ, SDHJ and RAHJ) as pathogen of $S$. litura infested corn were confirmed. Pathogenicity tests revealed the potential of EPF to be used as a biological control agent against target pest. The EPF found in this study (NKPT, SKHJ, SDHJ and RAHJ) originated from the corn rhizosphere. Here, it will provide more advantages if they were used for controlling $S$. litura on corn, since it is already well adapted to the corn field environment. However, further study is needed, especially on their optimum capability for controlling $S$. litura in the field as well as their stability and tolerance to environmental pressure and their effect on non-target organisms including natural enemies.

Application of EPF has been reported to have no or limited adverse effect on some natural enemies (Roy and Pell 2000). For example, application of B. bassiana showed no negative effect on the survival, duration, adult 
longevity, and fecundity of predator Coccinella undecimpunctata L. and Hippodamia variegate L. (Sayed et al. 2021). The EPF, Metarhizium brunneum, could be potentially applied against Delia radicum with a limited danger to its parasitoid Trybliographa rapae (Rännbäck et al. 2015). On the other hand, some other natural enemies have been reported negatively influenced by EPF application (Abbas 2020). Both strains of B. bassiana (AL1 and ATCC 74040) have also been reported negatively affecting Encarsia formosa, a parasitoid of Trialeurodes vaporariorum (Oreste et al. 2016).

Fluctuate damage of corn caused by S. litura was recognized in Lampung Province. The damage was slight (1 to $\leq 25 \%$ of plant damage) damage to crop failure ( $>85 \%$ of plant damage) with slight damage being the most damage observed in each year. The medium $(>25$ to $\leq 50 \%$ of plant damage) and severe ( $>50$ to $\leq 85 \%$ of plant damage) damage were rarely found in the field. During 2010-2019, the lowest damage area was observed in 2015, with 10 ha of slight plant damage without any medium damage, severe damage and crop failure.

Research performed by Fand et al. (2015) revealed that the development of all the immature stages of $S$. litura linearly increased until on or about $34-36{ }^{\circ} \mathrm{C}$, but not after this range of temperature. The temperature of $38{ }^{\circ} \mathrm{C}$ caused lethal to larval and pupal stages of S. litura and there will be no development to the next stage. Females were unable to lay eggs at low $\left(15^{\circ} \mathrm{C}\right)$ and high $\left(>35^{\circ} \mathrm{C}\right)$ temperatures. The highest damage of $S$. litura on cotton was observed when maximum temperature was in the range of $32-35{ }^{\circ} \mathrm{C}$ and the minimum temperature was 24-26 ${ }^{\circ} \mathrm{C}$ (Selvaraj et al. 2010). Alteration of temperature negatively influenced feeding performance of 2nd instar of S. litura to yellow cress (Rorippa dubia) (Pham and Hwang 2020). The outbreaks of this pest insect also occurred in heavy rainfall conditions after a long dry spell (Thanki et al. 2003).

The lowest damage of corn in Lampung Province was found in August and September gets together with high temperature and low rainfall.

\section{Conclusions}

Two species groups of EPF, i.e., Aspergillus oryzae and Beauveria bassiana were confirmed to be potentially used to control S. litura infesting corn in Lampung Province, Indonesia. It seems that this is the first report of the isolates of A. oryzae as EPF of S. litura in Indonesia. Identity of $A$. oryzae was verified by its inability to produce aflatoxin. Two isolates of $A$. oryzae (SKHJ and SDHJ) showed pathogenicity which was not significantly different from $B$. bassiana (NKPT). On the other hand, one of the isolates of $A$. oryzae (RAHJ) displayed significantly lower pathogenicity than B. bassiana. This isolate (RAHJ), however, showed pathogenicity which was not significantly different from the two other isolates of $A$. oryzae (SKHJ and SDHJ).

\begin{abstract}
Abbreviations
A. Aflatoxiformans: Aspergillus Aflatoxiformans; A. flavus: Aspergillus flavus; A. oryzae: Aspergillus oryzae; B. bassiana: Beauveria bassiana; BLAST: Basic Local Alignment Search Tool; CRD: Completely randomized design; Cl: Chloroform Isoamyl Alcohol; CTAB: Cetyl trimethylammonium bromide; EDTA: Ethylenediaminetetraacetic acid; InaCC: Indonesian Culture Collection; ITS: Internal Transcribed spacer; LSD: Least significance different; M. robertsii: Metarhizium robertsii; PCI: Phenol Chloroform Isoamyl Alcohol; PM: Percentage of Mortality; SDS: Sodium Dodecyl Sulfate; S. litura: Spodoptera litura; TBE: Tris HCL Boric Acid EDTA; T. molitor: Tenebrio molitor; YES: Yeast extract with supplements.
\end{abstract}

\section{Supplementary Information}

The online version contains supplementary material available at https://doi. org/10.1186/s41938-021-00473-8.

Additional file 1. Reference strains used in this study.

Additional file 2. Infected Tenebrio molitor cadaver at 14 days after laid on each of soil samples.

\section{Acknowledgements}

We thanks to Faculty of Agriculture, University of Lampung for permitting us using research facilities during this study and Indonesian Culture Collection (InaCC) for providing isolate of A. flavus BIO 3338.

\section{Authors' contributions}

YF and RS considered and planned the experiment. BS, II and SS carried out the isolation and pathogenicity test including rearing of Spodoptera litura for pathogenicity test. LTP, YF and RS performed molecular work and analysis. $\mathrm{MH}$ and RAR collected data on the plant damage area caused by S. litura as well as weather data. IGS and PP performed analysis and interpreted the plant damage and weather data. YF and RS prepared the manuscript. The authors provided responses and comments on the research flow, data analysis and interpretation as well as shape of the manuscript. All the authors have read and approved the final manuscript.

\section{Funding}

This research was funded by the Ministry of Research, Technology and Higher Education of Indonesia through Fundamental Research Grant No. 062/SP2H/ LT/DRPM/2018. The Ministry of Research, Technology and Higher Education of Indonesia provided funds for research materials as well as sequencing of PCR product.

Availability of data and material

The datasets used or analyzed in this study are available from the corresponding author on reasonable request.

\section{Declarations}

Ethics approval and consent to participate

Not applicable.

\section{Consent for publication}

Not applicable.

\section{Competing interests}

The authors declare that they have no competing interest regarding the publication of this manuscript. 


\begin{abstract}
Author details
${ }^{1}$ Department of Plant Protection, Faculty of Agriculture, University of Lampung, J. Soemantri Brojonegoro No. 1, Bandar Lampung, Indonesia. ${ }^{2}$ Department of Agrotechnology, Faculty of Agriculture, University of Lampung, Jl. Soemantri Brojonegoro No. 1, Bandar Lampung, Indonesia. ${ }^{3}$ Crop and Horticultural Plant Protection Agency of Lampung Province, Jl. ZA. Pagar Alam, No 1, Bandar Lampung, Indonesia.
\end{abstract}

Received: 23 July 2021 Accepted: 18 September 2021 Published online: 25 September 2021

\section{References}

Abbas MST (2020) Interactions between entomopathogenic fungi and entomophagous insects. Adv Entomol 8(3):130-146. https://doi.org/10. 4236/ae.2020.83010

Baker SE, Bennett JW (2008) An overview of the genus Aspergillus. In: Goldman GH, Osmani SA (eds) The Aspergilli: genomics, medical aspects, biotechnology, and research methods. CRC Press, Taylor and Francis Group, London, New York, pp 3-13

Bragard C, Dehnen-Schmutz K, Di Serio F, Gonthier P, Jacques MA, Miret JAJ, Justesen AF, Magnusson CS, Milonas P, Navas-Cortes JA, Parnell S, Potting R, Reignault PL, Thulke H-H, Van der Werf W, Vicent Civera A, Yuen J, Zappala L, Malumphy C, Czwienczek E, MacLeod A (2019) Pest categorization of Spodoptera litura. EFSA J 17(7):1-35. https://doi.org/10.2903/j.efsa.2019. 5765

Chuang WY, Lin WC, Hsieh YC, Huang CM, Chang SC, Lee TT (2019) Evaluation of the combined use of Saccharomyces cerevisiae and Aspergillus oryzae with phytase fermentation products on growth, inflammatory, and intestinal morphology in broilers. Animals 9(12):1-16. https://doi.org/10. 3390/ani9121051

Dhawan M, Joshi N (2017) Enzymatic comparison and mortality of Beauveria bassiana against cabbage caterpillar Pieris brassicae LINN. Braz I Microbiol 48(3):522-529. https://doi.org/10.1016/..bjm.2016.08.004

Direktorat Perlindungan Tanaman Pangan (2018) Petunjuk teknis pengamatan dan pelaporan organisme pengganggu tumbuhan dan dampak perubahan iklim (OPT-DPI) [Technical guidelines for observing and reporting plant pests and diseases and the impacts of climate change (OPT-DPI)]. Direktorat Jenderal Tanaman Pangan, Kementrian Pertanian Republik Indonesia, Jakarta, Indonesia ((in Indonesian))

Fand BB, Sul NT, Bal SK, Minhas PS (2015) Temperature impacts the development and survival of common cutworm (Spodoptera litura): simulation and visualization of potential population growth in india under warmer temperatures through life cycle modelling and spatial mapping. PLoS ONE 10(4):1-25. https://doi.org/10.1371/journal.pone.0124682

Fente CA, Ordaz JJ, Vázquez BI, Franco CM, Cepeda A (2001) New additive for culture media for rapid identification of aflatoxin-producing Aspergillus Strains. Appl Environ Microbiol 67(10):4858-4862. https://doi.org/10. 1128/AEM.67.10.4858-4862.2001

Frisvad JC, Hubka V, Ezekiel CN, Hong SB, Novakova A, Chen AJ, Arzanlou M, Larsen TO, Sklenar F, Mahakarnchanakul W, Samson RA (2019) Taxonomy of Aspergillus section Flavi and their production of aflatoxins, ochratoxins and other mycotoxins. Stud Mycol 93:1-63. https://doi.org/10.1016/j. simyco.2018.06.001

Gerpacio R, Labios J, Labios R, Diangkinay E (2004) Maize in the Philippines: production systems, constraints and research priorities. International Maize and Wheat Improvement Centre CIMMYT, Texcoco

Kumar S, Tamura K, Stecher G (2016) MEGA7: Molecular evolutionary genetics analysis version 7.0 for bigger datasets. Mol Biol Evol 33(7):1870-1874. https://doi.org/10.1093/molbev/msw054

Mora MAE, Castilho AMC, Fraga ME (2017) Classification and infection mechanism of entomopathogenic fungi. Arq Inst Biol (sao Paulo) 84:1-10. https://doi.org/10.1590/1808-1657000552015

Ngatimin SNA, Nasruddin A (2019) Comparison of insects biodiversity in green spinach ecosystem using farmer and commercial seeds. Trends Appl Sci Res 14(3):210-214. https://doi.org/10.3923/tasr.2019.210.214

Oreste M, Bubici G, Poliseno M, Tarasco E (2016) Effect of Beauveria bassiana and Metarhizium anisopliae on the Trialeurodes vaporariorum-Encarsia formosa system. J Pest Sci 89(1):153-160. https://doi.org/10.1007/ s10340-015-0660-4
Peterson SW (2008) Phylogenetic analysis of Aspergillus species using DNA sequences from four loci. Mycologia 100:205-226. https://doi.org/10. 3852/mycologia.100.2.205

Pham TA, Hwang SY (2020) High temperatures reduce nutrients and defense compounds against generalist Spodoptera litura F. in Rorippa dubia. Arthropod-Plant Interact 14:333-344. https://doi.org/10.1007/ s11829-020-09750-z

Purkan P, Baktir A, Sayyidah A (2016) Produksi enzim kitinase dari Aspergillus niger menggunakan limbah cangkang rajungan sebagai induser [Production of chitinase enzymes from Aspergillus niger using waste of crab shell as inducer]. J Kim Ris 1(1):34-41. https://doi.org/10.20473/jkr.v111.2440 (in Indonesian)

Rännbäck L-M, Cotes B, Anderson P, Rämert B, Meyling NV (2015) Mortality risk from entomopathogenic fungi affects oviposition behavior in the parasitoid wasp Trybliographa rapae. J Invertebr Pathol 124:78-86. https:// doi.org/10.1016/j.jip.2014.11.003

Rehner SA, Buckley E (2005) A Beauveria phylogeny inferred from nuclear ITS and EF1-alpha sequences: evidence for cryptic diversification and links to Cordyceps teleomorphs. Mycologia 97:84-98. https://doi.org/10.3852/ mycologia.97.1.84

Rehner S, Muro MD, Bischoff J (2006) Description and phylogenetic placement of Beauveria malawiensis sp. nov. (Clavicipitaceae, Hypocreales). Mycotaxon 98:137-145

Rehner SA, Minnis AM, Sung GH, Luangsa-ard JJ, Devotto L, Humber RA (2011) Phylogeny and systematics of the anamorphic, entomopathogenic genus Beauveria. Mycologia 103:1055-1073. https://doi.org/10.3852/ 10-302

Rosmiati A, Hidayat C, Firmansyah E, Setiati Y (2018) Potensi Beauveria bassiana sebagai agens hayati Spodoptera litura Fabr. pada tanaman kedelai [The potency of Beauveria bassiana as a biological control agent of Spodoptera litura on soybean]. J Agrikultura 29(1):43-47. https://doi.org/ 10.24198/agrikultura.v29i1.16925 (in Indonesian)

Roy HE, Pell JK (2000) Interactions between entomopathogenic fungi and other natural enemies: implications for biological control. Biocontrol Sci Technol 10(6):737-752. https://doi.org/10.1080/09583150020011708

Santos TS, de Freitas AC, Poderoso JCM, Hernandez-Macedo ML, Ribeiro GT, da Costa LP, MdaC M (2018) Evaluation of isolates of entomopathogenic fungi in the genera Metarhizium, Beauveria, and Isaria, and their virulence to Thaumastocoris peregrinus (Hemiptera: Thaumastocoridae). Fla Entomol 101(4):597-602. https://doi.org/10.1653/024.101.0421

Sayed SM, Ali EF, Al-Otaibi SS (2019) Efficacy of indigenous entomopathogenic fungus, Beauveria bassiana (Balsamo) Vuillemin, isolates against the rose aphid, Macrosiphum rosae L. (Hemiptera: Aphididae) in rose production. Egypt J Biol Pest Control 29:1-7. https://doi.org/10.1186/ s41938-019-0123-y

Sayed S, Elarrnaouty S-A, AlOtaibi S, Salah M (2021) Pathogenicity and side effect of indigenous Beauveria bassiana on Coccinella undecimpunctata and Hippodamia variegata (Coleoptera: Coccinellidae). Insects 12(1):1-11. https://doi.org/10.3390/insects12010042

Scheepmaker JWA, Butt TM (2010) Natural and released inoculum levels of entomopathogenic fungal biocontrol agents in soil in relation to risk assessment and in accordance with EU regulations. Biocon Sci Technol 20(5):503-552. https://doi.org/10.1080/09583150903545035

Schneider S, Rehner SA, Widmer F, Enkerli J (2011) A PCR-based tool for cultivation-independent detection and quantification of Metarhizium clade 1.J Invertebr Pathol 108:106-114. https://doi.org/10.1016/j.jip.2011.07.005

Selvaraj S, Adiroubane D, Ramesh V, Narayanan AL (2010) Impact of ecological factors on incidence and development of tobacco cut worm, Spodoptera litura Fabricius on cotton. J Biopest 3(1):43-46

Sewalt V, Shanahan D, Gregg L, Marta JL, Carrillo R (2016) The generally recognized as safe (GRAS) process for industrial microbial enzymes. Ind Biotechnol 12(5):295-302. https://doi.org/10.1089/ind.2016.0011

Sharma L, Oliveira I, Torres L, Marques G (2018) Entomopathogenic fungi in Portuguese vineyards soils: suggesting a 'Galleria-Tenebrio-bait method' as bait-insects Galleria and Tenebrio significantly underestimate the respective recoveries of Metarhizium (robertsii) and Beauveria (bassiana). MycoKeys 38:1-23. https://doi.org/10.3897/mycokeys.38.26970

Singh D, Son SY, Lee CH (2016) Perplexing metabolomes in fungal-insect trophic interactions: a terra incognita of mycobiocontrol mechanisms. Front Microbiol 7:1-13. https://doi.org/10.3389/fmicb.2016.01678 
Swibawa IG, Fitriana Y, Solikhin, Suharjo R, Susilo FX, Rani E, Haryani MS, Wardana RA (2020) Morpho-molecular identification and pathogenicity test on fungal parasites of guava root-knot nematode eggs in Lampung, Indonesia. Biodiversitas 21(3):1108-1115. https://doi.org/10.13057/ biodiv/d210334

Tarasco E, Kary NE, Fanelli E, Mohammadi D, Xingyue L, Mehrvar A, De Luca F, Troccoli A (2020) Modified bait insect technique in entomopathogens' survey from the arasbaran biosphere reserve (Iran). Redia 103:129-132. https://doi.org/10.19263/redia-103.20.20

Tesfaye D, Seyoum E (2010) Studies on the pathogenicity of native entomopathogenic fungal isolates on the cotton/melon aphid, Aphis gossypii (Homoptera: Aphididae) glover under different temperature regimes. Afr Entomol 18(2):302-312. https://doi.org/10.4001/003.018. 0215

Thanki KV, Patel GP, Patel JR (2003) Population dynamics of Spodoptera litura on castor Ricinus Communis. Indian J Entomol 65(3):347-350
White TJ, Bruns T, Lee S, Taylor JW (1990) Amplification and direct sequencing of fungal ribosomal RNA genes for phylogenetics. In: Innis MA, Gelfand DH, Sninsky JJ, White TJ (eds) PCR protocols: a guide to methods and applications. Academic Press Inc, New York

Zhang P, You Y, Song Y, Wang Y, Zhang L (2015) First record of Aspergillus oryzae (Eurotiales: Trichocomaceae) as an entomopathogenic fungus of the locust, Locusta migratoria (Orthoptera: Acrididae). Biocon Sci Technol 25(11):1285-1298. https://doi.org/10.1080/09583157.2015.1049977

Zulkifli NA, Zakaria L (2017) Morphological and molecular diversity of Aspergillus from corn grain used as livestock feed. Hayati J Biosci 24(1):26-34. https://doi.org/10.1016/j.hjb.2017.05.002

\section{Publisher's Note}

Springer Nature remains neutral with regard to jurisdictional claims in published maps and institutional affiliations.

\section{Submit your manuscript to a SpringerOpen ${ }^{\circ}$ journal and benefit from:}

- Convenient online submission

- Rigorous peer review

- Open access: articles freely available online

- High visibility within the field

- Retaining the copyright to your article

Submit your next manuscript at $\boldsymbol{\nabla}$ springeropen.com 